\title{
Prophylactic antiemetic effects in gynecologic patients receiving fentanyl IV-patient controlled analgesia: comparison of combined treatment with ondansetron and dexamethasone with metoclopramide and dexamethasone
}

\author{
Young Seok Jee, Hea-Jo Yoon, and Chang-Ha Jang \\ Department of Anesthesiology and Pain Medicine, Cheil General Hospital and Women Healthcare Center, Kwandong University \\ College of Medicine, Seoul, Korea
}

Background: This study was conducted to compare the efficacy of a combination of ondansetron and dexamethasone with that of metoclopramide and dexamethasone for prevention of postoperative nausea and vomiting (PONV) in gynecologic patients receiving fentanyl IV-patient controlled analgesia.

Methods: One hundred patients were divided into two groups at random. In Group O, $5 \mathrm{mg}$ of dexamethsone was administered after tracheal intubation, while $4 \mathrm{mg}$ of ondansetron was administered at the end of surgery. In Group M, $5 \mathrm{mg}$ of dexamethsone was administered after tracheal intubation and $20 \mathrm{mg}$ metoclopromide was administered at the end of surgery. During the experiment, the PONV was evaluated at regular intervals. In addition, the incidence of nausea, and vomiting and the numerical rating scale (NRS) of nausea was measured (range, $0-10$ ).

Results: The overall incidence of PONV in Group O was 22/50 (44\%) while that in Group M was 19/50 (38\%). There were no significant differences in the incidence of nausea, moderate to severe nausea (NRS of nausea, $4-10$ ), or vomiting between groups.

Conclusions: Treatment with a combination of $20 \mathrm{mg}$ metoclopramide and $5 \mathrm{mg}$ dexamethasone is an effective, safe, and inexpensive way to prevent PONV when compared to treatment with $4 \mathrm{mg}$ ondansetron and $5 \mathrm{mg}$ dexamethasone. (Korean J Anesthesiol 2010; 59: 335-339)

Key Words: Dexamethasone, Metoclopramide, Ondansetron, Postoperative nausea and vomiting.

Received: February 11, 2010. Revised: 1st, March 4, 2010; 2nd, April 14, 2010. Accepted: June 24, 2010.

Corresponding author: Hea-Jo Yoon, M.D., Department of Anesthesiology and Pain Medicine, Cheil General Hospital and Women Healthcare Center, Kwandong University College of Medicine, 1-19, Mukjeong-dong, Jung-gu, Seoul 100-380, Korea. Tel: 82-2-2000-7626, Fax: 82-2-20007784, E-mail: heajo7890@hanmail.net

두 This is an open-access article distributed under the terms of the Creative Commons Attribution Non-Commercial License (http:// creativecommons.org/licenses/by-nc/3.0/), which permits unrestricted non-commercial use, distribution, and reproduction in any medium, provided the original work is properly cited. 


\section{Introduction}

Postoperative nausea and vomiting (PONV) is a continuing concern in surgical patients. PONV can cause patient discomfort and dissatisfaction, and may delay recovery room and hospital discharge. The risk of PONV during gynecological surgery with postoperative intravenous-patient controlled Analgesia (IV-PCA) is higher because being female and IV-PCA are risk factors of PONV [1].

Ondansetron is a selective 5-hydroxytryptamine (5- $\left.\mathrm{HT}_{3}\right)$ receptor antagonist and dexamethason is a popular and effective combination therapy for prevention of PONV. However, ondansetron is an expensive drug; therefore, we should consider other optional combinations of drugs.

When used in standard clinical doses (10 mg IV), metoclopramide is ineffective for PONV prophylaxis [2]. Even in larger doses, metoclopramide does not appear to be an effective antiemetic [3]. However, Wallenborn et al. [4] reported that $25 \mathrm{mg}$ or $50 \mathrm{mg}$ metoclopramide combined with $8 \mathrm{mg}$ dexamethasone administered intraoperatively is more effective at preventing PONV than $8 \mathrm{mg}$ dexamethasone alone. Additionally, they reported that the addition of $25 \mathrm{mg}$ or $50 \mathrm{mg}$ metoclopramide to $8 \mathrm{mg}$ dexamethasone (administered intraoperatively) is an effective, safe, and inexpensive method of preventing postoperative nausea and vomiting.

This study was conducted to determine if treatment with a combination of $20 \mathrm{mg}$ metoclopromide and $5 \mathrm{mg}$ dexamethasone is as effective as treatment with $4 \mathrm{mg}$ ondansetron and 5 mg dexamethasone.

\section{Materials and Methods}

This study was conducted with appropriate institutional approval, and written informed consent was obtained from all patients. We evaluated 100 female adult American Society of Anesthesiologists (ASA) physical status I and II patients undergoing gynecological operation with IV-PCA. Exclusion criteria were hypersensitivity to metoclopramide, ondansetron or dexamethasone, use of antiemetic drugs, presence of extrapyramidal motor disease, current steroid medication, liver or renal disease, and peptic ulcer. The patients enrolled in this randomized study were assigned to one of two prophylactic antiemetic regimens using computer generated random numbers. There were no significant differences in age, body weight, height, ASA, or PONV risk factors between groups (Table 1).

Midazolam $3 \mathrm{mg}$ was administered intramuscularly 30 minutes prior to the induction of anesthesia. Anesthesia was induced with $1 \%$ lidocaine (30 mg), propofol (1.5 mg/kg), and fentanyl $(1 \mu \mathrm{g} / \mathrm{kg})$, and tracheal intubation was facilitated by administering rocuronium $(0.6 \mathrm{mg} / \mathrm{kg})$. Additional rocuronium was administered as required. Anesthesia was maintained using $2-3 \%$ sevoflurane (inspired concentration) and $50 \%$ nitrous oxide in oxygen. To reverse residual muscle relaxation, a combination of atropine $(0.5 \mathrm{mg})$ and neostigmine $(1 \mathrm{mg})$ were administered and the trachea was extubated. No opioids were given during the operation.

A PCA infusor (Anaplus ${ }^{\circledR}$ AP1020, E-Wha Fresenius Kabi, Inc., Gunpo, Korea) $100 \mathrm{ml}$ was prepared with 1,000 $\mu \mathrm{g}$ fentanyl and $150 \mathrm{mg}$ ketololac mixed with saline and then programmed to deliver a $0.5 \mathrm{ml}$ bolus and a $2 \mathrm{ml} / \mathrm{hr}$ continuous infusion with a 15-minute lockout interval.

In both groups, $5 \mathrm{mg}$ dexamethsone was administered after tracheal intubation. In Group $\mathrm{O}, 4 \mathrm{mg}$ ondansetron was administered at the end of surgery. In Group M, $20 \mathrm{mg}$ metoclopramide was administered at the end of surgery.

The incidence of PONV and NRS of nausea were recorded by anesthesiology doctors at the following postoperative periods: 0 to $1 \mathrm{hr}, 1$ to $6 \mathrm{hr}, 6$ to $12 \mathrm{hr}, 12$ to $24 \mathrm{hr}$, and 24 to $36 \mathrm{hr}$. The NRS of nausea was an 11-point scale, with 0 representing no nausea and 10 signifying the worst imaginable nausea. Delirium, extrapyramidal symptoms or arrhythmia were also recorded.

Rescue antiemetic (ondansetron $1 \mathrm{mg}$ ) was given IV if a patient experienced more than 15 minutes of nausea, experienced a vomiting episode, or if the patient requested antiemetic medication. Treatment was repeated if necessary.

Statistic calculations were performed using a standard statistical program (SPSS version 15.0, SPSS Inc., Chicago, IL, USA). The results were presented as the mean $\pm \mathrm{SD}$, and number of patients (\%). Age, body weight, height, and duration of operation (minutes) were compared using a Student's t-test. A chi-square test was used to analyze nominal data such as ASA, smoking habit, motion sickness or PONV history, type of surgery (laparoscopy/laparotomy) and overall incidence of

Table 1. Patients' Characteristics and PONV Risk Factors

\begin{tabular}{lcc}
\hline & $\begin{array}{c}\text { Group O } \\
(\mathrm{n}=50)\end{array}$ & $\begin{array}{c}\text { Group M } \\
(\mathrm{n}=50)\end{array}$ \\
\hline Age (yr) & $37.1 \pm 3.3$ & $38.7 \pm 3.2$ \\
Body weight (kg) & $60.2 \pm 8.9$ & $61.6 \pm 6.8$ \\
Height (cm) & $159.7 \pm 4.8$ & $159.5 \pm 3.6$ \\
ASA (I/II) & $47 / 3$ & $48 / 2$ \\
PONV risk factors & & 3 \\
$\quad$ Smoking habit & 12 & 13 \\
Motion sickness or PONV history & $40 / 10$ & $38 / 12$ \\
$\quad$ Type of surgery & & \\
$\quad$ (laparoscopy/laparotomy) & $110.5 \pm 20.9$ & $118.3 \pm 18.3$ \\
Duration of operation (min) & & \\
\hline
\end{tabular}

Values shown are the mean number of patients \pm SD or the number of patients (n). There were no significant differences between groups. PONV: postoperative nausea and vomiting, ASA: American Society of Anesthesiologists, Group O: ondansetron $4 \mathrm{mg}+$ dexamethasone $5 \mathrm{mg}$ iv, Group M: metoclopramide $20 \mathrm{mg}+$ dexamethasone $5 \mathrm{mg}$ iv. 
PONV. To compare the time based incidence of nausea and vomiting between two groups, a longitudinal analysis based on logistic regression of the repeated measurements was adopted. Each of the observations of NRS of nausea for a given patient was treated as a binomial repeated measure, with a score of $0-3$ indicating no or mild nausea and 4-10 indicating moderate to severe nausea. A P $<0.05$ was considered to indicate statistical significance.

\section{Results}

The overall incidence of PONV in Group O was 22/50 (44\%), while it was 19/50 (38\%) in Group M. No differences were observed between groups. There were also no significant differences in the incidence of nausea (Table 2), the incidence of moderate to severe nausea (Table 3 ) or the incidence of vomiting (Table 4) between groups. Furthermore, side effects such as delirium, extrapyramidal symptoms or arrhythmia were not observed.

\section{Discussion}

Without treatment, PONV occurs in $20-30 \%$ of the general surgical population and in up to $70-80 \%$ of high-risk surgical patients [5-7]. The adverse effects of PONV range from patientrelated distress to postoperative morbidity [8]. The most

Table 2. Incidence of Nausea

\begin{tabular}{lcc}
\hline & $\begin{array}{c}\text { Group O } \\
(\mathrm{n}=50)\end{array}$ & $\begin{array}{c}\text { Group M } \\
(\mathrm{n}=50)\end{array}$ \\
\hline $0-1$ hr postoperatively & $4(8)$ & $2(4)$ \\
$1-6$ hr postoperatively & $14(28)$ & $10(20)$ \\
$6-12$ hr postoperatively & $12(24)$ & $9(18)$ \\
$12-24$ hr postoperatively & $9(18)$ & $13(26)$ \\
$24-36$ hr postoperatively & $5(10)$ & $6(12)$ \\
\hline
\end{tabular}

Values shown are the number of patients (\%). There were no significant differences between groups. Group O: ondansetron 4 $\mathrm{mg}+$ dexamethasone $5 \mathrm{mg}$ iv, Group M: metoclopramide $20 \mathrm{mg}+$ dexamethasone $5 \mathrm{mg}$ iv.

Table 3. Incidence of Moderate to Severe Nausea

\begin{tabular}{lcc}
\hline & $\begin{array}{c}\text { Group O } \\
(\mathrm{n}=50)\end{array}$ & $\begin{array}{c}\text { Group M } \\
(\mathrm{n}=50)\end{array}$ \\
\hline $0-1$ hr postoperatively & $0(0)$ & $0(0)$ \\
$1-6$ hr postoperatively & $6(12)$ & $2(4)$ \\
$6-12$ hr postoperatively & $3(6)$ & $2(4)$ \\
$12-24$ hr postoperatively & $1(2)$ & $2(4)$ \\
$24-36$ hr postoperatively & $1(2)$ & $0(0)$ \\
\hline
\end{tabular}

Values shown are the number of patients (\%). There were no significant differences between groups. Group O: ondansetron 4 $\mathrm{mg}+$ dexamethasone $5 \mathrm{mg}$ iv, Group M: metoclopramide $20 \mathrm{mg}+$ dexamethasone $5 \mathrm{mg}$ iv. important patient-specific risk factors are female gender, nonsmoking status, and history of PONV/motion sickness [6,9-11]. High risk factors of PONV in Koreans are as follows in decreasing order: 1) being female, 2) history of PONV or motion sickness, 3) nonsmoker, 4) operative time of longer than 60 minutes and 5) patient controlled analgesia [1]. According to the above Korean PONV risk model, most of the patients evaluated in this study had four out of the five risk factors (Table 1); therefore, the overall incidence of PONV in Group O was 44\%, while it was $38 \%$ in Group M.

Hill et al. [12] found that prophylaxis in high-risk patients was more cost-effective than placebo due to the increased costs associated with nausea and vomiting. Specifically, they found that the additional costs associated with PONV in placebo patients were up to 100 times greater than those associated with prophylaxis using a generic antiemetic and that the cost of treating vomiting was three times greater than the cost of treating nausea. Similarly, a study evaluating dolasetron, droperidol, or no prophylaxis in high-risk patients found that prophylaxis with either of the two antiemetics was more costeffective than no prophylaxis and subsequent rescue therapy [13]. The use of prophylactic antiemetics should be based on valid assessment of the patient's risk for POV or PONV. In other words, antiemetic prophylaxis should be used only when the patient's individual risk is sufficiently high. This can be estimated by multiplying the expected incidence (baseline risk) by the relative risk reduction resulting from prophylaxis. This approach produces a clinically meaningful decrease in the risk of PONV $[5,14]$. However, more liberal prophylaxis is appropriate for patients for whom vomiting poses a particular medical risk, such as those with wired jaws, increased intracranial pressure, gastric or esophageal surgery, or when the anesthesia care provider determines the need or the patient has a strong preference to avoid PONV [8].

All 5- $\mathrm{HT}_{3}$ antagonists have been found to be equally antiemetic for the treatment of established PONV [15]. Combined treatment with metoclopramide and demenhydrinate is not effective when compared to treatment with metoclopramide alone [16].

Table 4. Incidence of Vomiting

\begin{tabular}{lcc}
\hline & $\begin{array}{c}\text { Group O } \\
(\mathrm{n}=50)\end{array}$ & $\begin{array}{c}\text { Group M } \\
(\mathrm{n}=50)\end{array}$ \\
\hline $0-1$ hr postoperatively & $0(0)$ & $1(2)$ \\
$1-6$ hr postoperatively & $5(10)$ & $4(8)$ \\
$6-12$ hr postoperatively & $6(12)$ & $2(4)$ \\
$12-24$ hr postoperatively & $4(8)$ & $4(8)$ \\
$24-36$ hr postoperatively & $1(2)$ & $2(4)$ \\
\hline
\end{tabular}

Values shown are the number of patients (\%). There were no significant differences between groups. Group O: ondansetron 4 $\mathrm{mg}+$ dexamethasone $5 \mathrm{mg}$ iv, Group M: metoclopramide $20 \mathrm{mg}+$ dexamethasone $5 \mathrm{mg}$ iv. 
In addition, $10 \mathrm{mg}$ metoclopramide plus metoclopramide 8 mg metoclopramide is less effective than combined treatment with $8 \mathrm{mg}$ dexamethasone and $4 \mathrm{mg}$ ondansetron [17]. A metaanalysis reported that $10 \mathrm{mg}$ metoclopramide was clinically ineffective and did not improve when combined with $8 \mathrm{mg}$ dexamethasone [2]. Moreover, $20 \mathrm{mg}$ of metoclopramide was found to be ineffective when compared with dolasetron for prevention of PONV [18]. However, $20 \mathrm{mg}$ of metoclopramide administered IV at the end of laparoscopic cholecystectomy resulted in a similar incidence of PONV as treatment with 8 mg ondansetron [19]. When a low dose is administered at the beginning of surgery, metoclopramide will be ineffective because of the short-lasting effect of metoclopramide. The addition of $50 \mathrm{mg}$ metoclopramide to $8 \mathrm{mg}$ dexamethasone (given intraoperatively) is an effective, safe, and inexpensive method of preventing postoperative nausea and vomiting. A reduced dose of $25 \mathrm{mg}$ metoclopramide administered intraoperatively with additional postoperative prophylaxis in high risk patients may be equally effective and cause fewer adverse drug reactions [4]. The recommended timing for administration of dexamethasone is at the induction of anesthesia rather than at the end of surgery [20]. Adverse events have not been noted after a single bolus dose of dexamethasone [21].

Prophylactic doses of droperidol (0.625-1.25 mg IV) are effective for the prevention of PONV [22,23]. The droperidol doses used for the management of PONV are extremely low, and droperidol is unlikely to be associated with significant cardiovascular events at these dosing levels [24-26]. However, many physicians have stopped using droperidol due to the US Food \& Drug Administration (FDA) black box restrictions on its use. As a result, droperidol for PONV is no longer available on the Korean market.

Combination therapy has superior efficacy than monotherapy for PONV prophylaxis $[27,28]$. Patients who are at high risk for PONV should receive prophylaxis with combination therapy. When different combinations were compared, no differences were observed between the $5-\mathrm{HT}_{3}$ receptor antagonist plus droperidol; $5-\mathrm{HT}_{3}$ receptor antagonist plus dexamethasone; and droperidol plus dexamethasone [7,29]. It has been suggested that, with combination therapy, dexamethasone doses should not exceed $10 \mathrm{mg}$ IV and that droperidol doses should not exceed $1 \mathrm{mg}$ IV. When used in combination with another drug, ondansetron doses in adults typically should not exceed 4 $\mathrm{mg}$, and can be much lower [30]. A large clinical trial of PONV revealed that $4 \mathrm{mg}$ ondansetron, $4 \mathrm{mg}$ dexamethasone, or 1.25 mg droperidol were effective (odds ratios about 0.5 ), and that combinations of these drugs had an additive effect [7].

In the present study, $20 \mathrm{mg}$ metoclopramide was found to be as effective as $4 \mathrm{mg}$ of ondansetron when combined with
$5 \mathrm{mg}$ dexamethasone. Although adverse reactions such as extrapyramidal symptoms are rare, clinicians should be aware of them and be familiar with suitable treatment options.

In conclusion, the results of our study demonstrate that treatment with a combination of $20 \mathrm{mg}$ metoclpromide and $5 \mathrm{mg}$ dexamethasone is an effective, safe, and inexpensive way to prevent PONV when compared with combined treatment with $4 \mathrm{mg}$ ondansetrone and $5 \mathrm{mg}$ dexamethasone in gynecologic patients receiving fentanyl IV-PCA.

\section{References}

1. Kim EJ, Ahn HJ, Park SH, Bang SR, Choi DH. Risk factors of postoperative nausea and vomiting: development of Korean risk model. Korean J Anesthesiol 2005; 48: 380-6.

2. Henzi I, Walder B, Tramèr MR. Metoclopramide in the prevention of postoperative nausea and vomiting: a quantitative systematic review of randomized, placebo-controlled studies. Br J Anaesth 1999; 83: 761-71.

3. Apfel CC, Kranke P, Katz MH, Goepfert C, Papenfuss T, Rauch S, et al. Volatile anaesthetics may be the main cause of early but not delayed postoperative vomiting: a randomized controlled trial of factorial design. Br J Anaesth 2002; 88: 659-68.

4. Wallenborn J, Gelbrich G, Bulst D, Behrends K, Wallenborn H, Rohrbach A, et al. Prevention of postoperative nausea and vomiting by metoclopramide combined with dexamethasone: randomised double blind multicentre trial. BMJ 2006; 333: 324.

5. Tramèr MR. A rational approach to the control of postoperative nausea and vomiting: evidence from systematic reviews. Part I. Efficacy and harm of antiemetic interventions, and methodological issues. Acta Anaesthesiol Scand 2001; 45: 4-13.

6. Apfel CC, Läärä E, Koivuranta M, Greim CA, Roewer N. A simplified risk score for predicting postoperative nausea and vomiting: conclusions from cross-validations between two centers. Anesthesiology 1999; 91: 693-700.

7. Apfel CC, Korttila K, Abdalla M, Kerger H, Turan A, Vedder I, et al. A factorial trial of six interventions for the prevention of postoperative nausea and vomiting. N Engl J Med 2004; 350: 2441-51.

8. Gan TJ, Meyer TA, Apfel CC, Chung F, Davis PJ, Habib AS, et al. Society for Ambulatory Anesthesia guidelines for the management of postoperative nausea and vomiting. Anesth Analg 2007; 105: 1615-28.

9. Cohen MM, Duncan PG, DeBoer DP, Tweed WA. The postoperative interview: assessing risk factors for nausea and vomiting. Anesth Analg 1994; 78: 7-16.

10. Stadler M, Bardiau F, Seidel L, Albert A, Boogaerts JG. Difference in risk factors for postoperative nausea and vomiting. Anesthesiology 2003; 98: 46-52.

11. Choi DH, Ko JS, Ahn HJ, Kim JA. A Korean predictive model for postoperative nausea and vomiting. J Korean Med Sci 2005; 20: 811-5.

12. Hill RP, Lubarsky DA, Phillips-Bute B, Fortney JT, Creed MR, Glass PS, et al. Cost-effectiveness of prophylactic antiemetic therapy with ondansetron, droperidol, or placebo. Anesthesiology 2000; 92: 95867.

13. Frighetto L, Loewen PS, Dolman J, Marra CA. Cost-effectiveness 
of prophylactic dolasetron or droperidol vs rescue therapy in the prevention of PONV in ambulatory gynecologic surgery. Can J Anaesth 1999; 46: 536-43.

14. Tramèr MR, Walder B. Number needed to treat (or harm). World J Surg 2005; 29: 576-81.

15. Kazemi-Kjellberg F, Henzi I, Tramèr MR. Treatment of established postoperative nausea and vomiting: a quantitative systematic review. BMC Anesthesiol 2001; $1: 2$.

16. Eberhart LH, Seeling W, Ulrich B, Morin AM, Georgieff M. Dimenhydrinate and metoclopramide alone or in combination for prophylaxis of PONV. Can J Anaesth 2000; 47: 780-5.

17. Maddali MM, Mathew J, Fahr J, Zarroug AW. Postoperative nausea and vomiting in diagnostic gynaecological laparoscopic procedures: comparison of the efficacy of the combination of dexamethasone and metoclopramide with that of dexamethasone and ondansetron. J Postgrad Med 2003; 49: 302-6.

18. Piper SN, Suttner SW, Rohm KD, Maleck WH, Larbig E, Boldt J. Dolasetron, but not metoclopramide prevents nausea and vomiting in patients undergoing laparoscopic cholecystectomy. Can J Anaesth 2002; 49: 1021-8.

19. Quaynor H, Raeder JC. Incidence and severity of postoperative nausea and vomiting are similar after metoclopramide 20 $\mathrm{mg}$ and ondansetron $8 \mathrm{mg}$ given by the end of laparoscopic cholecystectomies. Acta Anaesthesiol Scand 2002; 46: 109-13.

20. Wang JJ, Ho ST, Tzeng JI, Tang CS. The effect of timing of dexamethasone administration on its efficacy as a prophylactic antiemetic for postoperative nausea and vomiting. Anesth Analg 2000; 91: 136-9.

21. Henzi I, Walder B, Tramèr MR. Dexamethasone for the prevention of postoperative nausea and vomiting: a quantitative systematic review. Anesth Analg 2000; 90: 186-94.

22. Domino KB, Anderson EA, Polissar NL, Posner KL. Comparative efficacy and safety of ondansetron, droperidol, and metoclopramide for preventing postoperative nausea and vomiting: a meta-analysis. Anesth Analg 1999; 88: 1370-9.

23. Fortney JT, Gan TJ, Graczyk S, Wetchler B, Melson T, Khalil S, et al. A comparison of the efficacy, safety, and patient satisfaction of ondansetron versus droperidol as antiemetics for elective outpatient surgical procedures. S3A-409 and S3A-410 Study Groups. Anesth Analg 1998; 86: 731-8.

24. Gan TJ. Postoperative nausea and vomiting: can it be eliminated? JAMA 2002; 287: 1233-6.

25. White PF, Song D, Abrao J, Klein KW, Navarette B. Effect of low-dose droperidol on the QT interval during and after general anesthesia: a placebo-controlled study. Anesthesiology 2005; 102: 1101-5.

26. Charbit B, Albaladejo P, Funck-Brentano C, Legrand M, Samain E, Marty J. Prolongation of QTc interval after postoperative nausea and vomiting treatment by droperidol or ondansetron. Anesthesiology 2005; 102: 1094-100.

27. Habib AS, Gan TJ. Combination therapy for postoperative nausea and vomiting: a more effective prophylaxis? Ambul Surg 2001; 9: 5971.

28. Eberhart LH, Morin AM, Bothner U, Georgieff M. Droperidol and $5-\mathrm{HT}_{3}$-receptor antagonists, alone or in combination, for prophylaxis of postoperative nausea and vomiting: a meta-analysis of randomised controlled trials. Acta Anaesthesiol Scand 2000; 44: 1252-7.

29. Habib AS, El-Moalem HE, Gan TJ. The efficacy of the $5-\mathrm{HT}_{3}$ receptor antagonists combined with droperidol for PONV prophylaxis is similar to their combination with dexamethasone: a meta-analysis of randomized controlled trials. Can J Anaesth 2004; 51: 311-9.

30. Tramèr MR. A rational approach to the control of postoperative nausea and vomiting: evidence from systematic reviews. Part II. Recommendations for prevention and treatment, and research agenda. Acta Anaesthesiol Scand 2001; 45: 14-9. 